\title{
Local to Continental-Scale Variation in the Richness and Composition of an Aquatic Food Web
}

\section{Citation}

Buckley, Hannah L., Thomas E. Miller, Aaron M. Ellison, and Nicholas J. Gotelli. Forthcoming. Local to continental-scale variation in the richness and composition of an aquatic food web. Global Ecology and Biogeography 19.

\section{Published Version}

http://www3.interscience.wiley.com/journal/118545893/home

\section{Permanent link}

http://nrs.harvard.edu/urn-3:HUL.InstRepos:3627274

\section{Terms of Use}

This article was downloaded from Harvard University's DASH repository, and is made available under the terms and conditions applicable to Open Access Policy Articles, as set forth at http:// nrs.harvard.edu/urn-3:HUL.InstRepos:dash.current.terms-of-use\#OAP

\section{Share Your Story}

The Harvard community has made this article openly available.

Please share how this access benefits you. Submit a story.

\section{Accessibility}


3 Hannah L. Buckley ${ }^{1 *}$, Thomas E. Miller ${ }^{1}$, Aaron M. Ellison ${ }^{2}$, and Nicholas J. Gotelli ${ }^{3}$

4

$5 \quad{ }^{1}$ Department of Biological Science, Florida State University, Tallahassee, Florida 32306-4295, USA,

$6 \quad{ }^{2}$ Harvard University, Harvard Forest, 324 North Main Street, Petersham, Massachusetts 01366, USA,

$7 \quad{ }^{3}$ Department of Biology, University of Vermont, Burlington, Vermont 05405, USA, *Present address:

8 Department of Ecology, P.O. Box 84, Lincoln University, Canterbury, 7647, New Zealand

$9 \quad$ E-mail: hannah.buckley@lincoln.ac.nz.

10

11 Correspondence: Hannah Buckley, Department of Ecology, P.O. Box 84, Lincoln University,

12 Canterbury, 7647, New Zealand. E-mail: hannah.buckley@lincoln.ac.nz.

13 Phone: +64-3-321-8433

14 Fax: +64-3-325-3845

15

16 Running title: Pitcher-plant food webs from local to continental scales 


\section{ABSTRACT}

2 Aim: We investigated patterns of species richness and composition of the aquatic food web found in the

3 liquid-filled leaves of the North American purple pitcher plant, Sarracenia purpurea (Sarraceniaceae),

4 from local to continental scales.

5 Location: We sampled twenty pitcher-plant communities at each of thirty-nine sites spanning the

6 geographic range of S. purpurea - from northern Florida to Newfoundland and westward to eastern

7 British Columbia.

8 Methods: Environmental predictors of variation in species composition and species richness were

9 measured at two different spatial scales: among pitchers within sites and among sites. Hierarchical

10 Bayesian models were used to examine correlates and similarities of species richness and abundance

11 within and among sites.

12 Results: Ninety-two taxa of arthropods, protozoans, and bacteria were identified in the 780 pitcher

13 samples. The variation in the species composition of this multi-trophic level community across the

14 broad geographic range of the host plant was lower than the variation among pitchers within host-plant

15 populations. Variation among food webs in richness and composition was related to climate, pore-water

16 chemistry, pitcher-plant morphology, and leaf age. Variation in the abundance of the five most common

17 invertebrates was also strongly related to pitcher morphology and site-specific climatic and other

18 environmental variables. 
1 Main conclusions: The surprising result that these communities are more variable within their host-

2 plant populations than across North America suggests that the food web in $S$. purpurea leaves consists of

3 two groups of species: (1) a core group of mostly obligate pitcher-plant residents that have evolved

4 strong requirements for the host plant and that co-occur consistently across North America and (2) a

5 larger set of relatively uncommon, generalist taxa that co-occur patchily.

6

7 KEYWORDS

8 Food web, hierarchical Bayesian modeling, latitudinal gradients, Sarracenia purpurea, species

9 composition, species richness. 


\section{INTRODUCTION}

2 Theories that attempt to explain patterns of community structure generally operate at three spatial scales:

3 local habitats, metacommunities, and larger scales that encompass entire biogeographic ranges. At the

4 scale of local habitats, many theories addresses how small-scale processes, such as environmental

5 conditions and species interactions (especially competition and predation), determine population and

6 community patterns (Case, 1999). Empirical tests at this spatial scale show that interactions among

7 species and responses of species to environmental conditions should be most important in the

8 distributions and abundances of species. At the metacommunity scale, dispersal limitation and species

9 saturation are thought to affect species diversity within the constituent habitats and may even override

10 the effects of local interactions (see, e.g., Cornell \& Lawton, 1992). The metacommunity concept has

11 contributed to the development of significant theory (see Leibold et al., 2004; Holyoak et al., 2005), and

12 a growing number of experiments at this scale confirms that species interactions (see, e.g., Miller \&

13 Kneitel, 2005), habitat structure and resource availability (see, e.g., Srivastava, 2006), dispersal (see,

14 e.g., Kneitel \& Miller, 2003), and, more recently, genetics (see, e.g. Whitham et al., 2006; Crutsinger et

15 al., 2009) can be important determinants of among-community patterns.

Theories predicting community structure at even larger spatial scales are uncommon (Srivastava,

17 2005). At continental scales, distribution and abundance patterns may reflect broad environmental

18 gradients (Huston, 1994; Rosenzweig, 1995; Hawkins et al., 2003) and historical and evolutionary

19 processes (Ricklefs \& Schluter, 1993). Most empirical work at these spatial scales is based on simple 
1 correlation analysis of geographic gradients in species richness (Gotelli et al., 2009) and is often

2 restricted to groups of potential competitors or trophic guilds (see, e.g. Rivadeneira et al., 2002) or to

3 single taxonomic groups such as mammals, birds, or trees (see, e.g., Rahbek \& Graves, 2001; Stevens \&

4 Willig, 2002). Geographic studies incorporating taxa interacting across trophic levels will almost

5 certainly be more revealing than studies that are taxonomically or trophically restricted (Ellingsen \&

6 Gray, 2002; Andrew \& Hughes, 2004). Further, although most large-scale studies of diversity are

7 conducted at a single spatial grain, for example, latitude-longitude blocks of particular size (Rahbek \&

8 Graves, 2001; Arita et al., 2005), processes controlling distribution and abundance often operate at

9 multiple spatial scales that may be revealed only by sampling at multiple grain sizes (see, e.g., Levin,

10 1992; Mittelbach et al., 2001). Teasing apart the influences of regional and local processes therefore

11 requires sampling across trophic levels and at multiple spatial scales (He \& Condit, 2007).

12 Here, we describe a study of a complete food web at two spatial scales across the entire

13 geographic range of the community: the bacteria, protozoans, rotifers, and arthropods that inhabit water-

14 filled pitchers of the North American purple pitcher plant Sarracenia purpurea L. (see Appendix S1 in

15 Supporting Information and Fig. 1). This detritus-based aquatic food web is restricted to discrete habitat

16 units (rain-filled leaves) of a single host plant that itself occurs in circumscribed habitats such as bogs

17 and pine savannas. This system provides three naturally discrete hierarchical sampling units: pitchers

18 within plants, plants within populations, and populations within the plant's geographic range. We

19 compared patterns of food-web species richness and composition in pitchers of similar age within and 
2 species richness in this food web across the geographic range of the host plant (Buckley et al., 2003), but

3 we did not analyse the variation in species composition, environmental drivers of that variation, or scale 4 dependence of those drivers.

6 abundances are controlled by a combination of processes, including interactions, resources, and dispersal

7 (Miller \& Kneitel, 2005; Gotelli \& Ellison, 2006, Hoekman et al., 2009). Our large-scale analysis can

8 provide insight into the relative importance of these factors. For example, higher abundance of the

9 filter-feeding larvae of the pitcher-plant mosquito, Wyeomyia smithii (Coq.), is known to reduce the

10 abundances of protozoans and rotifers (Addicott, 1974; Miller et al., 2002; Trzcinski et al., 2005a, b;

11 Hoekman, 2007) but to have more variable effects on the abundance of microbes (Kneitel \& Miller,

12 2002; Hoekman, 2007; Peterson et al., 2008). Therefore, if this pattern scales up to the geographic

13 scale, we should observe a strong relationship among pitchers and among sites between the abundance

14 of $W$. smithii and the composition and richness of protozoans, rotifers, and, to a lesser extent, bacteria.

15 On the other hand, the addition of resources to this system has been shown to increase the abundances of

16 mites, rotifers, protozoans, and bacteria (Kneitel \& Miller, 2002; Hoekman, 2007). Therefore, similarly,

17 if this pattern scales up, we should observe strong correlations between food-web richness and

18 composition and the size and morphology of pitchers, which control habitat volume (Gotelli \& Ellison,

19 2006), and environmental variables related to resource availability. 
2 predicts we should see variation in community patterns with latitude (Buckley et al., 2003), and we

3 expected sites to vary more than individual pitchers within sites in species richness and composition of

4 food webs, because the broad geographic range of $S$. purpurea encompasses large differences in climate,

5 historical factors, and bog characteristics. We investigated the question, 'What drives the distribution

6 and abundance of species at the within- and among-Sarracenia population scales?' We answered this

7 question by (1) comparing variations in the food web at these two spatial scales and (2) determining the

8 relative effects of resource-based factors, interactions, and abiotic and biotic site variation at these two

9 spatial scales on species richness, species composition, and the abundance of individual species.

\section{METHODS}

\section{Study species}

12 Sarracenia purpurea is a long-lived (>50 years), carnivorous, perennial plant that grows as a rosette of

13 pitcher-shaped leaves. It occurs in nutrient-poor wetlands-ombrotrophic bogs, poor fens, sand plains,

14 and longleaf-pine savannas-along the eastern coastal plain of North America and westward across

15 Canada and the northern mid-western states of the United States (Schnell, 2002; Fig. 1), spanning $30^{\circ}$ of

16 latitude and $70^{\circ}$ of longitude. In the northernmost portion of its range, the growing season is short, the

17 seasonal temperature variation is large, and $S$. purpurea var. purpurea is primarily restricted to

18 Sphagnum-peat bogs. In the south-eastern coastal plain, the growing season is long, seasonal

19 temperature variation is small, and $S$. purpurea var. venosa grows in pine savannas and seepage swamps. 
1 In the southernmost part of the range (the Florida Panhandle, Alabama, and Mississippi), S. purpurea

2 ssp. venosa var. burkii (= S. rosea, sensu Naczi et al., 1999) grows year-round, experiences relatively

3 little seasonal temperature variation, and occurs mostly in the sandy soils of pine savannas.

5 sky and fill with rainwater and snow. The plants attract a variety of prey, primarily ants and other small

6 arthropods, which fall into the water-filled pitchers and drown. These aquatic microhabitats (generally 3

7 to $50 \mathrm{~mL}$ of fluid) are also colonized by a variety of arthropods, rotifers, protozoans, and bacteria that

8 form a detritus-based food web (Appendix S1; see also Addicott, 1974; Bradshaw \& Creelman, 1984;

9 Miller \& Kneitel, 2005). Obligate inhabitants of S. purpurea pitchers include larvae of three dipterans-

10 Wyeomyia smithii, the midge Metriocnemus knabi Coq., and the sarcophagid Fletcherimyia fletcheri

11 (Aldrich)—and one histiostomatid mite, Sarraceniopus gibsoni (Nesbitt). Bacteriovores include the

12 bdelloid rotifer Habrotrocha rosa Donner and numerous protozoan species (Addicott, 1974; Cochran-

13 Stafira \& von Ende, 1998). Bacterial abundances are generally high (10 $10^{4}$ to $10^{9}$ per mL; Kneitel \&

14 Miller, 2002) and can vary at different spatial scales (Harvey \& Miller, 1996; Petersen et al., 2008).

15 Less common members of this community include loricate rotifers, cladocerans, copepods, amphipods,

16 nematodes, and multi-cellular algae (Addicott, 1974; Miller et al., 1994; Bledzki \& Ellison 2003). The

17 resource base of this community is the prey captured by the leaf, which is first shredded by the flesh

18 flies and midges and then decomposed and mineralized by the microbes. The plant takes up phosphorus

19 and nitrogen (and possibly small proteins and amino acids) from the pitcher fluid (Bradshaw \& 
1 Creelman, 1984; Butler et al., 2008). Bacteria are themselves fed on by a host of bacteriovorous

2 protozoans and rotifers, primarily $H$. rosa, and the mite (Kneitel \& Miller, 2002; Butler et al., 2008;

3 Karagatzides et al., in press). The mosquito larvae are omnivorous filter feeders that ingest pieces of

4 dead prey, small protozoans, and bacteria (Addicott, 1974). The flesh fly is an omnivorous top predator

5 that feeds on the mosquito larvae (Butler et al., 2008), shreds prey, and also cannibalizes conspecifics

6 (Forsyth \& Robertson, 1975).

\section{Data collection}

8 Between May and mid-September 2001, we sampled food webs in S. purpurea pitchers at thirty-nine

9 sites throughout the plant's geographic range (Fig. 1). Site-selection criteria included a minimum plant

10 population size (at least fifty plants), accessibility, availability of sampling permits, and the use of only

11 native populations. Each food web was sampled only once at a site; we standardized for seasonal effects

12 by sampling each population approximately four weeks after spring flowering; widely separated sites

13 were sampled at similar times by different research teams that all followed identical sampling protocols.

14 Latitude and longitude of each sampled S. purpurea population were determined by global

15 positioning system (Magellan GPS 315). Spatially referenced elevation and climate data for all sites

16 were obtained from the Landscape Analysis and Application Section of the Canadian Forest Service

17 (McKenney et al., 2006). Elevation and climate data for points nearest to the study-site locations were

18 queried in ArcGIS 9.0. The area covered by each population was estimated in the field with transect 
2 plant; the percentage covers of sphagnum, trees, shrubs, forbs, and graminoids were recorded.

4 (that could be reached on foot); transect length therefore varied with population areal extent. Along this

5 transect, the closest plant to each of twenty evenly spaced points was selected, and, on this plant, the

6 oldest pitcher produced during the current season was sampled. As leaf production begins immediately

7 after flowering, most sampled communities should therefore be 3-5 weeks old. Where the pitcher of the

8 current season could not be sampled because of leaf damage, we sampled the youngest pitcher from the

9 previous growing season. Wolfe (1981) showed that younger leaves captured more prey than leaves

10 more than 30 days old, so pitcher age in our analyses may be correlated with prey-capture frequency. We collected pitcher contents with sterile plastic pipettes, recorded their total volume, and then

12 divided the fluid into a Diptera-free, 1.5-mL sample, placed in a sterile microcentrifuge tube, and the

13 remainder, which was placed in a 50-mL sterile macrocentrifuge tube. Both portions were refrigerated

14 and returned to the lab, where arthropods and other large species in the large sample were counted and

15 identified to the lowest taxonomic resolution possible (10× magnification for arthropod identification,

$16100 \times$ magnification for the identification of rotifers and large protozoans; identification and

17 nomenclature followed Pennak, 1989). A 0.1-mL subsample of the smaller sample was serially diluted

$18\left(10^{-3}\right.$ and $\left.10^{-5}\right)$ by sterile techniques. Three replicates from each dilution were plated on full-strength

19 PCB agar plates. Emergent bacterial colonies were separated into morphotypes based on color, texture, 
1 and transparency. After both 3 and 10 days, for the plate from each dilution on which colony number

2 was closest to being between thirty and 300, the number colonies of each bacterial morphotype was

3 recorded. The counts from the three replicate plates at that dilution were then averaged to yield relative

4 abundance of each bacterial morphotype within individual pitchers. Some of these culturable

5 morphotypes were later tentatively identified by standard sequencing of 16S rDNA (Pepper \& Gerba,

6 2005).

Plant measurements made in the field included rosette diameter along the widest axis and the

8 number of pitchers with and without water. The length, width at the widest point, keel width, and lip

9 width of each sampled pitcher were measured with digital callipers (Ellison et al., 2004).

To quantify environmental characteristics of sites, we used a clean Tygon tube to extract five 50-

$11 \mathrm{~mL}$ pore-water samples from capped and perforated PVC tubes $(50 \mathrm{~cm}$ long $\times 2.5 \mathrm{~cm}$ in diameter) that

12 were sunk into the peat at even intervals along our sample transect. For each water sample, we

13 measured $\mathrm{pH}$ and calcium content (mg/L) with Orion ion-sensitive electrodes (Thermo Electron Corp,

14 Woburn, Massachusetts, USA) and phosphate $\left(\mathrm{PO}_{4}-\mathrm{P}\right)$, nitrate $\left(\mathrm{NO}_{3}-\mathrm{N}\right)$, and ammonium $\left(\mathrm{NH}_{4}-\mathrm{N}\right)($ all in

$15 \mathrm{mg} / \mathrm{L}$ ) spectrophotometrically according to U.S. EPA standard methods (Clesceri et al., 1998). Pore-

16 water samples were not taken at the eight southern sites with dry sandy soils.

\section{Data analysis}

18 Variation in species composition 
1 We assessed variation in food-web species composition among sites and pitchers by calculating a mean

2 similarity from presence data using the Jaccard similarity index, which represents the average similarity

3 in species composition of each sampled community to every other. High mean similarity indicates that

4 samples within the matrix are compositionally homogeneous and that species turnover among samples is

5 low; a mean similarity of 1.0 would mean that all samples were identical (Scheiner, 1992). Mean

6 similarity was generated both for the site-by-species matrix and for all thirty-nine of the pitcher-by-

7 species matrices (one matrix for each site). The average of the mean pitcher similarities yielded a mean

8 pitcher similarity for sites.

9 Data reduction

10 The presence of arthropods (including rotifers for the purposes of these analyses), protozoans, and

11 bacterial morphotypes that occurred in more than $1 \%$ of the 592 pitchers across thirty sites (those sites

12 for which pore water samples were taken) were analysed separately by principal-coordinates analysis

13 (PCoA) implemented in the labdsv package version 1.3.1 in R (R Development Core Team, 2006) on the

14 basis of a Steinhaus distance matrix. The Steinhaus metric, which is similar to the Sorenson distance

15 metric, is suitable for presence data (Roberts, 2008) and resulted in the best spread of pitchers in the

16 ordination space (Legendre \& Legendre, 1998). The site scores for the first two axes of each PCoA

17 (PCoA-1 and PCoA-2) were used as measures of variation in 'species' composition for arthropods,

18 protozoans, and bacteria because they explained the most variation in each case. 
3 Mefford, 2006) to reduce the number of pitcher-plant morphology variables, vegetation-cover variables,

4 and site-level variables for the 30 sites. For the pitcher-plant morphology variables, we extracted the

5 first three principal components, and for the vegetation-cover variables and the site-level variables, we

6 extracted only the first two principal components; these PC axes were used as predictor variables in

7 subsequent analyses.

$8 \quad$ Predictors of variation in species richness and composition

$9 \quad$ Because pitchers were nested within sites and because we wanted to relate pitcher species richness and

10 composition to variables measured at both the pitcher and site scales, we constructed two-level,

11 hierarchical Bayesian models (Gelman \& Hill, 2007) for three groups: arthropods + rotifers, protozoans,

12 and bacteria. We used varying intercept models without interactions terms because ours was an

13 exploratory study with many predictor variables. Species richnesses of the three groups were

14 normalised by a natural-log transformation. Species composition, as measured by PCoA axis scores,

15 was normally distributed for the three groups. Both species richness and composition were modeled as

16 Gaussian processes with identity-link functions. Although richness is a count variable and therefore

17 more correctly modelled as untransformed values with a Poisson distribution, the methods for

18 calculating the variance explained (see below) are only available for models that assume a Gaussian

19 distribution. We used non-informative priors for all parameters in all models (Gelman \& Hill, 2007). 
1 Species richness and composition were modeled separately for the three different groups. Each

2 dependent variable $(y)$, richness or composition at the pitcher level, was modelled as a function of

3 pitcher-level predictor variables, $x$, and site-level predictor variables, $u$. The pitcher-level model takes

4 the form $y_{i} \sim N\left(\alpha_{j}+\beta x_{i}, \sigma_{y}^{2}\right)$, for $i=1, \ldots, n_{j}$, where $y_{i}$ is the richness or composition of the $i^{\text {th }}$ pitcher, $\alpha_{j}$

5 is the regression intercept for the $j^{\text {th }}$ site, $\beta$ is the matrix of coefficients for the pitcher-level predictors,

$6 \quad \sigma_{y}^{2}$ is the pitcher-level regression error, and $n$ is the total number of pitchers. The hierarchical model

7 treats the pitcher-level intercept terms, $\alpha$, as though they come from a normal distribution across sites

8 and models them as $\alpha_{j} \sim N\left(\gamma+\theta u_{j}, \sigma^{2}{ }_{\alpha}\right)$, for $j=1, \ldots, J$, where $\gamma$ is the site-level regression intercept and $\theta$

9 is the matrix of coefficients for the site-level predictors, $\sigma_{\alpha}^{2}$ is the site-level regression error, and $J$ is the

10 total number of sites.

11 In all models, the same set of environmental predictor variables was used (pitcher age, pitcher

12 PCs 1-3, vegetation PCs 1-2, and site PCs 1-2). The models for protozoans and bacteria also contained

13 abundances of mosquitoes and midges as additional pitcher-level predictors. Fully conditional models

14 that included all predictors were taken as the final result in all cases because methods for determining

15 the importance of predictor variables, model comparison, and model reduction using hierarchical

16 Bayesian methods are still controversial (Gelman \& Hill, 2007).

Models were fit by Markov chain Monte Carlo iteration with the BRugs package (Thomas et al.,

18 2006) of R version 2.7.1 (R Development Core Team, 2006). We assessed model convergence visually

19 for three simultaneously running Markov chains of at least 50,000 iterations, after a 10,000-iteration 
1 burn-in period, and thinned it at every tenth value to reduce the effects of autocorrelation on parameter

2 estimates.

To obtain the relative amount of variance in the data at the pitcher level and the site level, we

4 calculated the intraclass correlation coefficient as the ratio of pitcher-level variance to the sum of the

5 pitcher-level variance and the site-level variance from an unconditional model that did not contain

6 predictor variables (Gelman \& Hill, 2007). The variance explained by the predictor variables for the full

7 model was calculated as $R^{2}=1-\left(\operatorname{mean}\left(\operatorname{var}\left(y_{i}-\hat{y}_{i k}\right)\right) / \operatorname{var}\left(y_{i}\right)\right)$. In other words, we took the residuals for

8 each pitcher from each iteration and calculated the variance across iterations for each pitcher. We then

9 divided the mean of these variances by the variance in the dependent variable and subtracted the result

10 from 1 to obtain the variance explained.

11 Predictors of variation in the presence of obligate pitcher-plant residents

12 The presence of the four obligate pitcher-plant residents-Wyeomyia smithii, Metriocnemus knabi,

13 Fletcherimyia fletcheri, and Sarraceniopus gibsoni-together with that of H. rosa, was modelled with

14 two-level, hierarchical Bayesian models with varying intercept terms without interaction terms. The

15 presence of each species was modelled as a Bernoulli process with a logit link function and non-

16 informative priors for all parameters in all models. Each dependent variable (y), the presence of each

17 species at the pitcher level, was modelled as a function of pitcher-level predictor variables, $x$, and site-

18 level predictor variables, $u$. The pitcher-level model takes the form $y_{i} \sim \operatorname{Bern}\left(\alpha_{j}+\beta x_{i}\right)$, for $i=1, \ldots, n_{j}$,

19 where $y_{i}$ is the presence or absence of the species in the $i^{\text {th }}$ pitcher, $\alpha_{j}$ is the regression intercept for the $j^{\text {th }}$ 
1 site, $\beta$ is the matrix of coefficients for the pitcher-level predictors, and $n$ is the total number of pitchers.

2 The second level of the hierarchical model was the same as that described above for species richness and

3 composition, as were the predictor variables.

4 RESULTS

\section{Species composition of all trophic levels}

6 Across all sites, we found a total of thirteen arthropod + rotifer species, forty-eight protozoan

7 morphospecies, and twenty-nine bacterial morphotypes (the most common are listed in Appendix S2).

8 Individual pitchers contained a mean of $3 \pm 1.2$ (SD) arthropod species (Wyeomyia smithii and

9 Metriocnemus knabi were most common), $2 \pm 1.4$ protozoan morphospecies (most abundant were

10 Poterioochromonas malhamensis, Bodo sp., and Colpoda near sp. insula), and $6 \pm 2.1$ bacterial

11 morphotypes. At the site level, we recorded $6 \pm 1.4$ arthropods, $9 \pm 3.8$ protozoan morphospecies, and

$1217 \pm 2.6$ bacterial morphotypes. Three of the four obligate pitcher-plant species (W. smithii, M. knabi,

13 and $S$. gibsonii) and the rotifer $H$. rosa were found at virtually all sites, whereas $F$. fletcheri was found at

14 only twenty-seven of the thirty-nine sites. The number of rare taxa was very large; of the ninety taxa

15 encountered, only fifty-six occurred in more than $1 \%$ of pitchers. Plots of the number of individuals

16 versus the number of occupied sites (Appendix S3) illustrate that most taxa were relatively rare and

17 occurred at $<50 \%$ of the sampled sites.

18 Mean similarity in species composition among sites was $0.54 \pm 0.04$. In other words, on average,

19 for any given site, just over half the species were the same as at any other given site. The similarity of 
1 sites varied geographically; sites in western and central Canada had consistently higher among-site

2 similarity (and richness) than eastern sites (Fig. 1). Contrary to our initial prediction, the mean

3 similarity among pitchers within sites was much lower $(0.36 \pm 0.04)$ than the similarity among sites.

\section{Data reduction}

5 The first two axes of the PCoA of the fifty-six species occurring in at least $1 \%$ of pitchers sampled at the

6 thirty sites without missing data and for which pore water data were available accounted for $47 \%$ of the

7 variation in occurrence of arthropods + rotifers, $40 \%$ in occurrence of protozoans, and $21 \%$ in

8 occurrence of bacteria. The variation accounted for by these first two axes primarily reflected variation

9 in the presence of the more common species within pitchers. For example, for the arthropods + rotifers,

10 the loadings on the first PCoA axis were positively related to the presence of $W$. smithii and $M$. knabi

11 and negatively related to the presence of $S$. gibsoni and H. rosa. The loadings on the second axis were

12 negatively related only to the presence of $W$. smithii. For protozoans, the loadings on the first axis were

13 negatively related to the presence of Bodo sp and those on the second to the presence of

14 Poterioochromonas sp. For bacteria, the loadings on the first axis were strongly and positively related

15 to the presence of Klebsiella pneumoniae, a species of Cytophagales, and to the presence of unidentified

16 morphotype number 46. Loadings on this axis were strongly negatively related to presence of

17 Flectobacillus sp. Those on the second axis were strongly positively related to the presence of $K$.

18 pneumoniae, Flectobacillus sp., and morphotype number 46 and negatively to that of Pseudomonas sp. 
2 morphology data accounted for $75 \%$ of the variation among pitchers in their morphological

3 characteristics (Appendix S4). The loadings on the first pitcher PCA axis ('size') increased with rosette

4 diameter, pitcher height, and pitcher volume. Those on the second ('habitat area') increased with pitcher

5 volume. Those on the third ('pitcherness') were positively associated with smaller keels and greater lip

6 widths.

The first two axes from the PCA of the vegetation data accounted for $64 \%$ of the variation in

8 local habitat characteristics (Appendix S4). High scores for the first vegetation PCA indicated habitats

9 at which pitchers were surrounded by a higher percentage cover of sphagnum and a lower percentage

10 cover of forbs. High scores on the second indicated habitats with a higher percentage cover of trees and

11 a lower percentage cover of graminoids.

12 The first two axes from the PCA of environmental characteristics accounted for $74 \%$ of the

13 variation among the thirty sites with pore-water data (Appendix S4). The loadings on the first axis

14 described a geographic gradient in a whole range of spatially structured environmental conditions

15 moving from west to east and north to south across the distribution of sites. Sites with high scores on

16 this axis were at low elevations in the southeast United States, had long growing seasons with high mean

17 temperatures and precipitation, and had low annual variation in both of these variables. Sites with high

18 scores were more acidic and had lower levels of calcium and ammonium in pore water. Sites with high 
1 values on the second axis had more basic pore water that contained more phosphorus but less

2 ammonium.

\section{Hierarchical modelling of food-web richness and composition at the thirty pore-water sites}

4 Species richness

5 Between $70 \%$ and $84 \%$ of the variation in richness of arthropods, rotifers, protozoans, and bacteria was

6 at the pitcher level rather than at the site level (Table 1). The hierarchical models revealed that richness

7 of arthropods+ rotifers was higher in larger, older pitchers (pitcher PC 1) that were not flattened (pitcher

8 PC 3), were surrounded by more Sphagnum (vegetation PC 1), and occurred at sites in the north-western

9 part of the host-plant range, where $\mathrm{pH}$ and $\mathrm{PO}_{4}$ are lower (site $\mathrm{PCs} 1$ and 2; Fig. 2a). Protozoan richness

10 was positively associated with midge abundance and pitcher age and negatively associated with older,

11 flatter pitchers (pitcher PC 3) that occurred at higher-latitude sites (Fig. 2b). Pitchers that contained

12 greater richness of bacterial morphotypes were older and larger (pitcher PC 1) and occurred at sites at

13 higher latitudes (site PC 1) (Fig. 2c). Despite these patterns, the predictor variables did not account for

14 much of the observed variation in species richness (maximum $R^{2}=0.32$; Table 1 ).

15 Species composition

16 The first PCoA axis describing variation in arthropod + rotifer species composition was positively

17 related to geographic location (site PC 1) and negatively to pitcher size (pitcher PC 1; Fig. 3a). The

18 second was related to geographic location (site PC 1), pitcher size (pitcher PC 1), and pitcher age and

19 was marginally related to the relative cover of Sphagnum (vegetation PC 1) (Fig. 3b). Composition of 
1 protozoan taxa (PCoA 1) was related positively to pitcher age and negatively to midge density, mosquito

2 density, and Sphagnum cover (vegetation PC 1; Fig. 3c). Protozoan PCoA 2 was positively associated

3 with plants that had greater numbers of water-filled leaves (pitcher PC 2) and that occurred at sites in the

4 north-western part of the host-plant range, with lower $\mathrm{PO}_{4}$ concentration in the pore water and lower $\mathrm{pH}$

5 (site PC 1; Fig. 3d). Finally, variation in bacterial composition (PCoA 1) was positively related to the

6 density of midge larvae in pitchers, pitcher age, and plants that had greater numbers of water-filled

7 leaves (pitcher PC 2). This bacterial-composition axis was also marginally positively related to

8 Sphagnum cover surrounding pitchers (vegetation PC 1; Fig. 3e). Bacterial PCoA 2 was negatively

9 related to the density of midge larvae in pitchers and positively associated with pitchers that were

10 pitcher-like in morphology (pitcher PC 3) and greater tree cover surrounding the plant (vegetation PC 2).

11 This axis was also marginally negatively related to plant size (pitcher PC 1; Fig. 3). As with the species-

12 richness models, the variance explained by the hierarchical models was low and never exceeded 36\%

13 (Table 1).

14 Presence of the four obligate pitcher-plant residents and Habrotrocha rosa

15 Wyeomyia smithii was more likely to occur in pitchers that were more pitcher-like in morphology

16 (pitcher PC 3) and on plants surrounded by higher tree cover (vegetation PC 2) and less likely to occur

17 in older, smaller pitchers (pitcher PC 1; Fig. 4a). Fletcherimyia fletcheri was more likely to occur in

18 younger pitchers from the current season and in pitchers on plants surrounded by greater Sphagnum

19 cover (vegetation PC 1) and was marginally associated with geographic location (site PC 1; Fig. 4b). 
1 Metriocnemus knabi was more likely to occur in larger (pitcher PC 1), older pitchers from previous

2 seasons and was marginally associated with pitchers that were pitcher-like in morphology (pitcher PC 3)

3 on plants surrounded by higher tree cover (vegetation PC 2) and lower Sphagnum cover (vegetation PC

4 1; Fig. 4c). The mite Sarraceniopus gibsoni was more likely to occur in larger (pitcher PC 1), younger

5 pitchers that were more pitcher-like (pitcher PC 3; Fig. 4d). Habrotrocha rosa was more likely to occur

6 in older pitchers that were more pitcher-like (pitcher PC 3) on plants that were surrounded by lower

7 Sphagnum cover (vegetation PC 1) at higher-latitude sites (site PC 1; Fig. 4e).

\section{DISCUSSION}

9 We found significant variation in the composition of the food web among Sarracenia populations; our

10 ability to explain that variation, and the variation in species richness, using measured predictor variables,

11 was limited (Table 1). This result is not surprising because we were considering a community that is

12 highly variable at small spatial scales (Buckley et al., 2004) and that spans such a large geographical

13 range, but contrary to our initial prediction, variation in food-web composition was greater (species

14 turnover was higher) at the among-pitcher than at the among-site scale. Among-site similarity values

15 were high (Fig. 1), and particular taxa — the obligate pitcher-plant residents and Habrotrocha rosa-

16 were consistently common across the range of the host plant, although $F$. fletcheri had a more north-

17 easterly distribution. These species therefore appear to have stronger associations with the host plant

18 itself than with large-scale variation in environmental conditions. The consistent and somewhat unusual

19 habitat provided by the pitcher itself may have resulted in a highly specialized suite of co-habiting 
1 species that have all evolved to use the same habitat provided by the host plant. In fact, some studies

2 have suggested that the plant derives only minor benefits from carnivory (e.g., Chapin \& Pastor, 1995;

3 Bott et al., 2008). If the species that use the water-filled leaves of $S$. purpurea depend on their host plant

4 to a greater degree than each plant or leaf benefits from the presence of these associated species, then the

5 food-web composition may be structured by the consistent environment of the leaf itself and not by the

6 relatively large variation in seasonality, productivity, and abiotic factors across the plant's range.

7 Although we do not fully understand the exchanges of resources and other benefits between the host

8 plant and these species and among the species themselves (see, e.g., Bledzki \& Ellison, 1998; Mouquet

9 et al., 2008), they appear to represent a community-level mutualism, in which at least some species

10 benefit from the presence of other species in the community and their host plant.

11 The high among-pitcher variation we observed has also been noted in previous studies of this

12 system (e.g., Addicott, 1974; Harvey \& Miller, 1996; Buckley et al., 2004; Peterson et al., 2008) and

13 appears to be due in part to the effects of pitcher 'age' (Fish \& Hall, 1978; Trzcinski et al., 2003, 2005a;

14 Miller \& Kneitel, 2005). Alone among the environmental variables we measured, pitcher age explained

15 variation in almost all dependent variables modelled, including the species richness of the three groups,

16 species composition, and the abundance of the obligate residents (Figs 2-4). Because pitchers from

17 previous growing seasons will have had more time to accumulate species and for competitive exclusion

18 and predation to take effect (especially where the growing season is long), we would expect the older

19 pitchers we sampled to differ significantly from younger pitchers in food-web richness and composition. 
1 Pitchers usually provide habitat for up to a year (Miller \& Kneitel, 2005), but herbivory, especially by

2 noctuid larvae (Atwater et al., 2006), eventually damages the leaf's ability to hold water.

Few previous studies have found results similar to ours, in which the variance in food-web

4 richness and composition is primarily within, rather than among, sites. Most studies, which have been

5 of single taxonomic groups, have found significant among-site variation associated with climate and

6 latitude (e.g., Rahbek \& Graves, 2001; Andrew \& Hughes, 2004; Willig \& Bloch, 2006), and others

7 have found significant effects of local environmental variables on community structure (e.g., Ellingsen

8 \& Gray, 2002). Perhaps the most relevant comparison would be with widespread tree-hole and

9 bromeliad-inhabiting aquatic food webs that are detritus-based and have mosquitoes as top predators.

10 Contrary to our results, tree-hole invertebrate assemblages have high among-site variation (see, e.g.,

11 Kitching, 2000; Srivastava, 2005), which may be related to the high variation in the regional pool of

12 available species (Srivastava, 2005). Bromeliads have a comparatively small geographic range, with

13 some variation in trophic structure (Srivastava et al., 2008), but the biogeography of bromeliad food

14 webs has not been well studied (García-Robledo et al., 2005).

The relative homogeneity at large spatial scales of these pitcher-plant inquiline communities, as

16 compared to tree-hole and other similar communities, may be due to the nature of the relationship with

17 their plant host. Many of the component species are obligate inhabitants of the relatively ephemeral

18 habitat provided by S. purpurea leaves, and their geographic distributions almost perfectly coincide with

19 that of the host plant. The exact nature of the relationship between the plant and its constituent 
community is not well understood: it was originally thought to be an obligate mutualism (see, e.g.,

2 Bradshaw \& Creelman, 1984), but more recent work has suggested that the plant receives no benefit

3 from the aquatic community in its leaves (Butler et al., 2008) or even that some of the species parasitize

4 the host plant (Mouquet et al., 2008). Regardless of the effects on the host plants, many inquiline

5 species appear to have evolved strong requirements for the host plant. This adaptation to the unique

6 habitat found inside the leaves may act to minimize any effects of large-scale variation in environmental

7 conditions.

Interestingly, processes acting at both large and small scales were important in determining the

$9 \quad$ variation in pitcher-level species richness and composition for all taxa and all taxon groups we analysed

10 (Figs 2-4). The among-pitcher variation was in many cases related to the geographic and spatially

11 structured environmental variables represented by 'site PC 1', which summarised a large set of

12 confounded variables (Appendix S4) that may represent a wide range of potential ecological drivers of

13 species' distribution and abundance, such as the effects of day length or temperature on behaviour or

14 metabolic rates. When determinants of richness and composition for local communities are considered

15 at small scales, much unexplained variation may be accounted for by processes traditionally seen to be

16 operating at much larger scales, such as the impact of landscape or climatic factors (Ricklefs \& Schluter,

17 1993).

18 Our previous analysis of latitudinal gradients in species richness for this dataset (Buckley et al.,

19 2003) showed that the abundance of mosquito larvae ( W. smithii) was correlated with species richness of 
1 the lower trophic levels (protozoa and bacteria) and might have resulted in the reverse trend of

2 decreasing richness toward the equator. The analysis reported here used only the bog sites where pore

3 water was collected and, surprisingly, found no strong relationship between mosquito larval abundance

4 and the richness or composition of the lower trophic levels of the food web. The mean abundance of

5 mosquito larvae at the excluded, mostly southern, pine-savannah sites was $1.7 \pm 1.1$ individuals per mL

6 of pitcher fluid ( \pm 1 S.D.), whereas the mean of the sites included in the current analysis was only $0.7 \pm$

7 0.5, so habitat factors may drive mosquito abundance and, in turn, influence the lower tropic levels at

8 high densities.

9 As predicted, the richness and composition of the food webs were related to resource availability

10 and habitat volume. Midge abundance, which has been related to higher resource availability at the

11 lower trophic levels (Hoekman et al., 2009), was related to protozoan richness and the composition of

12 protozoans and bacteria (Figs 2 and 3). Pitcher size (pitcher PC 1), which represents the amount of

13 habitat volume available (Gotelli \& Ellison, 2006), explained variation in several aspects of food-web

14 richness and composition. Among-pitcher variation in richness and composition was also associated

15 with differences in pitcher shape and plant size (pitcher PC 2 and PC 3). This result shows that large

16 scale environmental drivers of plant morphology (Ellison et al., 2004) affect the availability of resources

17 and consequently the structure of these pitcher-plant food webs in such a way as to generate geographic

18 patterns in richness and composition. 
2 the food webs found in the leaves of pitcher plants provide important insight into the mechanisms

3 behind geographic variation in food-web species richness and composition. The wide range of the host

4 plant allows us to quantify the interacting effects of local and geographic abiotic and biotic variables on

5 species richness and composition at these multiple spatial scales. Future studies of the biogeography of

6 entire communities must address both the relationship between species and their habitat and the

7 relationships among species within the habitat, by investigating patterns and processes across a wide

8 range of spatial scales. 


\section{ACKNOWLEDGEMENTS}

2 We thank all those who were involved and helped with field and lab work, in particular, Jim

3 Cuthbertson, Chris Oakley, and Sarah Yinger. Brad Case performed the GIS data analysis and created

4 the maps. The manuscript was greatly improved by comments from Gary Mittelbach and three

5 anonymous reviewers. This research was funded by the National Science Foundation under grants

6 DEB-0083617 to TEM, AME, and NJG and DEB-0091776 to TEM.

7

8 
2 Addicott, J.F. (1974) Predation and prey community structure: an experimental study of the effect of mosquito larvae on the protozoan communities of pitcher plants. Ecology, 55, 475-492.

4 Andrew, N.R. \& Hughes, L. (2004) Species diversity and structure of phytophagous beetle assemblages along a latitudinal gradient: predicting the potential impacts of climate change. Ecological Entomology, 29, 527-542.

Arita, H.T, Rodríguez, P. \& Vázquez-Domínguez, E. (2005) Continental and regional ranges of North American mammals: Rapoport’s rule in real and null worlds. Journal of Biogeography, 32, 961-971.

10 Atwater, D.Z., Butler, J.L. \& Ellison, A.M. (2006) Spatial distribution and impacts of moth larvae on northern pitcher plants. Northeastern Naturalist, 13, 43-56.

Bledzki, L.A. \& Ellison, A.M. (1998) Population growth and production of Habrotrocha rosa Donner (Rotifera: Bdelloidea) and its contribution to the nutrient supply of its host, the northern pitcher plant, Sarracenia purpurea L. (Sarraceniaceae). Hydrobiologia, 385, 193-200 species records for North America and New England. Hydrobiologia, 497, 53-62.

17 Bott T., Meyer, G.A. \& Young, E.B. (2008) Nutrient limitation and morphological plasticity of the carnivorous pitcher plant Sarracenia purpurea in contrasting wetland environments. New Phytologist, 180, 631-641. 

Sarracenia purpurea and its inhabitants. American Midland Naturalist, 112, 294-304.

3 Buckley, H.L., Burns, J.H., Kneitel, J.M., Walters, E.L., Munguia, P. \& Miller, T.E. (2004) Small-scale patterns in community structure of Sarracenia purpurea inquiline communities. Community Ecology, 5, 181-188.

6 Buckley, H.L., Miller, T.E., Ellison, A.M. \& Gotelli, N.J. (2003) Reverse latitudinal trends in species richness of pitcher-plant food webs. Ecology Letters, 6, 825-829.

8 Butler, J.L., Gotelli, N.J. \& Ellison, A.M. (2008) Linking the brown and green: nutrient transformation and fate in the Sarracenia microecosystem. Ecology, 89, 898-904.

10 Case, T.J. (1999) An illustrated guide to theoretical ecology. Oxford University Press, Oxford.

11 Chapin, C.T. \& Pastor, J. (1995) Nutrient limitation in the northern pitcher plant Sarracenia purpurea. Canadian Journal of Botany, 73, 728-734.

13 Clesceri, L.S., Greenberg, A.E. \& Easton, A.D. (1998) Standard methods for the examination of water and wastewater, 20th edn. American Public Health Association, Washington, D.C.

15 Cochran-Stafira, D.L. \& von Ende, C.N. (1998) Integrating bacteria into food webs: studies with Sarracenia purpurea inquilines. Ecology, 79, 880-898.

17 Cornell, H.V. \& Lawton, J.H. (1992) Species interactions, local and regional processes, and limits to the richness of ecological communities: a theoretical perspective. Journal of Animal Ecology, 61, 1-12. 

structure across spatial scales. Ecology Letters, 12, 285-292. along the Norwegian continental shelf? Journal of Animal Ecology, 71, 373-389. purpurea (Sarraceniaceae): geographic, environmental, and taxonomic correlates. American Journal of Botany, 91, 1930-1935.

8 Fish, D. \& Hall, D.W. (1978) Succession and stratification of aquatic insects inhabiting the leaves of the insectivorous pitcher plant Sarracenia purpurea. American Midland Naturalist, 99, 172-183.

10 Forsyth, A.B. \& Robertson, R.J. (1975) $K$ reproductive strategy and larval behaviour of the pitcher plant sarcopagid fly, Blaesoxipha fletcheri. Canadian Journal of Zoology, 53, 174-179.

12 García-Robledo, C., Quintero-Marín, P. \& Mora-Kepfer, F. (2005) Geographic variation and succession of arthropod communities in inflorescences and infructescences of Xanthosoma (Araceae).

15 Gelman, A. \& Hill, J. (2007) Data analysis using regression and multilevel/hierarchical models. Cambridge University Press, Cambridge.

17 Gotelli, N.J. \& Ellison, A.M. (2006) Food-web models predict species abundance in response to habitat change. PLoS Biology, 44, e324. 

R.R., Graves, G.R., Green, J., Grytnes, J.-A., Jiang, Y.-H., Jetz, W., Lyons, S. K., McCain, C., Magurran, A.E., Rahbek, C., Rangel, T.F.L.V.B., Soberón, J., Webb, C.O. \& Willig, M. R. (2009) Patterns and causes of species richness: a general simulation model for macroecology. Ecology Letters 12, 873-886.

6 Harvey, E. \& Miller, T.E. (1996) Variance in composition in inquiline communities in leaves of Sarracenia purpurea L. on multiple spatial scales. Oecologia, 108, 562-566.

8 Hawkins, B.A., Field, R., Cornell, H.V., Currie, D.J., Guégan, J.-F., Kaufman, D.M., Kerr, J.T., Mittelbach, G.G., Oberdorff, T., O’Brien, E.M., Porter, E.E., \& Turner, J.R.G. (2003) Energy, water, and broad-scale geographic patterns of species richness. Ecology, 84, 3105-3117.

11 He, F. \& Condit, R. (2007) The distribution of species: occupancy, scale, and rarity. Scaling Press, Cambridge. repeated field experiment using the pitcher plant (Sarracenia purpurea) inquiline community.

17 Hoekman, D., Winston, R. \& Mitchell, R. (2009) Top-down and bottom-up effects of a processing detritivore. Journal of the American Benthological Society, 28, 552-559. 

ecological communities. University of Chicago Press, Chicago.

3 Huston, M.A. (1994) Biological diversity: the coexistence of species on changing landscapes. Cambridge University Press, Cambridge.

5 Karagatzides, J.D., Butler, J.L. \& Ellison, A.M. (in press) The pitcher plant Sarracenia purpurea can directly acquire organic nitrogen and short-circuit the inorganic nitrogen cycle. PLoS One.

7 Kitching, R.L. (2000) Food webs and container habitats: the natural history and ecology of phytotelmata. Cambridge University Press, Cambridge.

9 Kneitel, J.M. \& Miller, T.E. (2002) Resource and top-predator regulation in the pitcher plant (Sarracenia purpurea) inquiline community. Ecology, 83, 680-688.

11 Kneitel, J.M. \& Miller, T.E. (2003) Dispersal rates affect community composition in metacommunities of Sarracenia purpurea inquilines. American Naturalist, 162, 165-171.

13 Legendre, P. \& Legendre, L. (1998) Numerical ecology, 2nd English edn. Elsevier Science, Amsterdam.

15 Leibold, M.A., Holyoak, M., Mouquet, N., Amarasekare, P., Chase, J.M., Hoopes, M.F., Holt, R.D., Shurin, J.B., Law, R., Tilman, D., Loreau, M. \& Gonzalez, A. (2004) The metacommunity concept: a framework for multi-scale community ecology. Ecology Letters, 7, 601-613.

18 Levin, S.A. (1992) The problem of pattern and scale in ecology. Ecology, 73, 1943-1967. 

MjM Software, Gleneden Beach, Oregon.

3 McKenney, D., Papadopol, P., Campbell, K., Lawrence, K. \& Hutchinson, M. (2006) Spatial models of Canada- and North America-wide 1971/2000 minimum and maximum temperature, total precipitation and derived bioclimatic variables. Forestry Research Applications Technical Note No. 106. Canadian Forest Service, Great Lakes Forestry Centre, Sault Ste. Marie, Canada.

Miller, T.E., Cassill, D., Johnson, C., Kindell, C., Leips, J., McInnes, D., Bevis, T., Mehlman, D. \& Richard, B. (1994) Intraspecific and interspecific competition of Wyeomyia smithii (Coq.) (Culicidae) in pitcher plant communities. American Midland Naturalist, 131, 136-145.

10 Miller, T.E. \& Kneitel, J.M. (2005) Inquiline communities in pitcher plants as a prototypical metacommunity. Metacommunities: spatial dynamics and ecological communities (ed. by M. Holyoak, M.A. Leibold and R.D. Holt), pp. 122-145. University of Chicago Press, Chicago.

13 Miller, T.E., Kneitel, J.M. \& Burns, J.H. (2002) Effect of community structure on invasion success and rate. Ecology, 83, 898-905.

15 Mittelbach, G.G., Steiner, C.F., Scheiner, S.M., Gross K.L., Reynolds, H.L., Waide, R.B., Willig, M.R., Dodson, S.I. \& Gough, L. (2001) What is the observed relationship between species richness and productivity? Ecology, 82, 2381-2396. 
1 Mouquet, N., Daufresne, T., Miller, T.E. \& Gray, S. (2008) Modelling the relationship between a pitcher plant (Sarracenia purpurea) and its phytotelma community: mutualism or parasitism? Functional Ecology, 22, 728-737

4 Naczi, R.F.C., Soper, E.M., Case, F.W. \& Case, R.B. (1999) Sarracenia rosea (Sarraceniaceae), a new species of pitcher plant from the southeastern United States. Sida, 18, 1183-1206.

6 Pennak, R.W. (1989) Freshwater invertebrates of the United States. John Wiley, New York.

7 Pepper, I.L. and Gerba, C.P. (2005) Environmental microbiology: a laboratory manual. Elsevier Academic Press, Amsterdam.

9 Peterson, C.N., Day S., Wolfe, B.E., Ellison, A.M., Kolter R. \& Pringle A. (2008) A keystone predator controls bacterial diversity in the pitcher-plant (Sarracenia purpurea) microecosystem. Environmental Microbiology, 10, 2257-2266.

14 Rahbek, C. \& Graves, G.R. (2001) Multiscale assessment of patterns of avian species richness. Proceedings of the National Academy of Sciences of the USA, 98, 4534-4539.

16 Ricklefs, R.E. \& Schluter, D. (1993) Species diversity in ecological communities: historical and geographical perspectives. University of Chicago Press, Chicago. 
1 Rivadeneira, M., Fernandez, M. \& Navarrete, S.A. (2002) Latitudinal trends of species diversity in rocky intertidal herbivore assemblages: spatial scale and the relationship between local and regional species richness. Marine Ecology Progress Series, 245, 123-131.

4 Roberts, D. (2008) http://ecology.msu.montana.edu:/labdsv/R/labs, accessed 21 October 2008.

5 Rosenzweig, M.L. (1995) Species diversity in space and time. Cambridge University Press, Cambridge.

6 Scheiner, S.M. (1992) Measuring pattern diversity. Ecology, 73, 1860-1867.

7 Schnell, D.E (2002) Carnivorous plants of the United States and Canada, 2nd edn. Timber Press, Portland, Oregon.

9 Srivastava, D.S. (2005) Do local processes scale to global patterns? The role of drought and the species pool in determining treehole insect diversity. Oecologia, 145, 205-215.

11 Srivastava, D.S. (2006) Habitat structure, trophic structure and ecosystem function: interactive effects in 12 a bromeliad-insect community. Oecologia, 149, 493-504.

13 Srivastava, D.S., Trzcinski, M.K., Richardson, B.A. \& Gilbert, B. (2008) Why are predators more sensitive to habitat size than their prey? Insights from bromeliad insect food webs. American Naturalist 172, 761-771.

16 Stevens, R.D. \& Willig, R.D. (2002) Geographic ecology at the community level: perspectives on the diversity of New World bats. Ecology, 83, 545-560.

18 Thomas, A., O’Hara, B., Ligges, U. \& Sturtz, S. (2006) Making BUGS Open. R News, 6, 12-17. 

scales. Ecological Entomology, 28, 482-489.

3 Trzcinski, M.K., Walde, S.J. \& Taylor, P.D. (2005a) Local interactions in pitcher plant communities scale-up to regional patterns in distribution and abundance. Environmental Entomology, 34, $1464-1470$.

6 Trzcinski, M.K., Walde, S.J. \& Taylor, P.D. (2005b) Stability of pitcher-plant microfaunal populations depends on food web structure. Oikos, 110, 146-154.

8 Whitham, T.G., Bailey, J.K., Schweitzer, J.A., Shuster, S.M., Banger, R.K., Leroy, C.J., Lonsdorf, E.V., Allan, G.J., DiFazio, S.P., Potts, B.M., Fischer, D.G., Gehring, C.A., Lindroth, R.L., Marks, J.C., Hart, S.C., Wimp, G.M. \& Wooley, S.C. (2006) A framework for community and ecosystem genetics: from genes to ecosystems. Nature Reviews Genetics, 7, 510-523.

Willig, M.R. \& Bloch, C.P. (2006) Latitudinal gradients of species richness: a test of the geographic area hypothesis at two spatial scales. Oikos, 112, 163-173.

14 Wolfe, L.M. (1981) Feeding behavior of a plant: differential prey capture in old and new leaves of the pitcher plant (Sarracenia purpurea). American Midland Naturalist, 106, 352-359. 


\section{Supplementary Material}

2 Additional Supporting Information can be found in the on-line version of this article:

3 Appendix S1 Diagram of the food web occurring within the pitchers of the North American purple

4 pitcher plant, Sarracenia purpurea.

5 Appendix S2 The 56 taxa that occurred in $>1 \%$ of 780 pitcher-plant (Sarracenia purpurea) leaves

6 sampled at thirty-nine sites throughout the plant's North American range.

7 Appendix S3 Abundance-occupancy relationships for (a) arthropods + rotifers, (b) protozoans, and (c)

8 bacteria.

9 Appendix S4 Results from the principal-components analysis of pitcher- and plant-morphology

10 variables (pitcher level), vegetation variables measured within a $1-\mathrm{m}^{2}$ quadrat centred on each plant

11 (pitcher level), and site-level environmental variables.

12

13 Please note: Blackwell Publishing is not responsible for the content or functionality of any Supporting

14 Information supplied by the authors. Any queries (other than missing material) should be directed to the

15 corresponding author for the article. 
2 Hannah Buckley is a Senior Lecturer in Ecology at Lincoln University. Her research interests include

3 community ecology and macroecology. She is particularly interested in understanding spatial patterns in 4 community structure. 
1 Table 1 Proportion of variance calculated from variance partitioning showing the relative amount of

2 variation in the data for each hierarchical Bayesian model at the pitcher and site levels. $R^{2}$ values give

3 the amount of variation explained by all predictors for each model.

\begin{tabular}{|c|c|c|c|}
\hline \multirow[b]{2}{*}{ Model } & \multicolumn{2}{|c|}{ Proportion of variation } & \multirow[b]{2}{*}{$R^{2}$} \\
\hline & Pitcher level & Site level & \\
\hline Arthropod richness & 0.70 & 0.30 & 0.32 \\
\hline Protozoan richness & 0.84 & 0.15 & 0.15 \\
\hline Bacterial richness & 0.77 & 0.23 & 0.21 \\
\hline Arthropod composition axis 1 & 0.64 & 0.36 & 0.35 \\
\hline Arthropod composition axis 2 & 0.81 & 0.19 & 0.19 \\
\hline Protozoan composition axis 1 & 0.84 & 0.16 & 0.15 \\
\hline Protozoan composition axis 2 & 0.61 & 0.39 & 0.36 \\
\hline Bacterial composition axis 1 & 0.81 & 0.19 & 0.18 \\
\hline Bacterial composition axis 2 & 0.64 & 0.36 & 0.33 \\
\hline
\end{tabular}

4 


\section{Figure legends}

2 Figure 1 Maps showing the locations of the thirty-nine sampled sites (circles) across the geographic

3 range of Sarracenia purpurea (shaded area) in North America. The size of each point represents the

4 number of taxa occurring within pitchers at that site out of the 90 encountered across all sites; larger

5 points represent sites with a higher number of taxa. Percentage similarity in species composition of all

6 taxa is represented by the shading of the points: sites with $<70 \%$ similarity are white, those between 70

7 and $80 \%$ similarity are grey, and those with $>80 \%$ are black.

8 Figure 2 Plots showing the mean values (filled circles) and 95\% posterior credibility intervals (lines) for

9 parameter estimates from hierarchical Bayesian models for the pitcher richness of (a) arthropods +

10 rotifers, (b) protozoans, and (c) bacteria. Intervals that do not overlap zero are considered to be

11 significantly different from zero. For protozoan and bacterial richness, the two additional predictors

12 were the number of mosquito larvae and the number of midge larvae present in pitchers. Models do not

13 include data from seven southern sites at which pore-water data were not collected or two sites with

14 missing environmental data. PC, principal component. PC site 1: Sites with high scores were at low

15 elevations in the southeast United States, had long growing seasons with high mean temperatures and

16 precipitation, and had low annual variation in both of these variables. Sites with high scores were more

17 acidic and had lower levels of calcium and ammonium in pore water. PC site 2: Sites with high values

18 on the second axis had more basic pore water that contained more phosphorus but less ammonium. PC

19 vegetation 1: High scores indicated habitats at which pitchers were surrounded by a higher percentage 
1 cover of sphagnum and a lower percentage cover of forbs. PC vegetation 2: High scores indicated

2 habitats with a higher percentage cover of trees and a lower percentage cover of graminoids. PC pitcher

31 ('size'): High scores indicated high with rosette diameter, pitcher height, and pitcher volume. PC

4 pitcher 2 ('habitat area'): High scores indicated high pitcher volume. PC pitcher 3 ('pitcherness'):

5 indicated smaller keels and greater lip widths on pitchers.

6 Figure 3 Plots showing the mean values (filled circles) and 95\% posterior credibility intervals (lines) for

7 parameter estimates from hierarchical Bayesian models for the pitcher composition of (a) arthropod +

8 rotifer composition axis 1, (b) arthropod + rotifer composition axis 2, (c) protozoan axis 1, (d) protozoan

9 axis 2, (e) bacterial composition axis 1, and (f) bacterial composition axis 2. Intervals that do not

10 overlap zero are considered to be significantly different from zero. For protozoan and bacterial

11 composition, the two additional predictors were the number of mosquito larvae and the number of midge

12 larvae present in pitchers. Models do not include data from seven southern sites at which pore-water

13 data were not collected or two sites with missing environmental data. PC, principal component; see

14 Figure 2 caption for further explanation.

15 Figure 4 Maps showing the proportion of pitchers occupied (above) and plots (below) showing the

16 mean values (filled circles) and 95\% posterior credibility intervals (lines) for parameter estimates from

17 hierarchical Bayesian models for the presence in pitchers of (a) the mosquito Wyeomyia smithii, (b) the

18 sarcophagid Fletcherimyia fletcheri, (c) the midge Metriocnemus knabi, (d) the histiostomatid mite

19 Sarraceniopus gibsoni, and (e) the bdelloid rotifer Habrotrocha rosa. Intervals that do not overlap zero 
2 seven southern sites at which pore-water data were not collected or two sites with missing environmental

3 data. PC, principal component; see caption of Figure 2 for further explanation.

4 
Figure 1

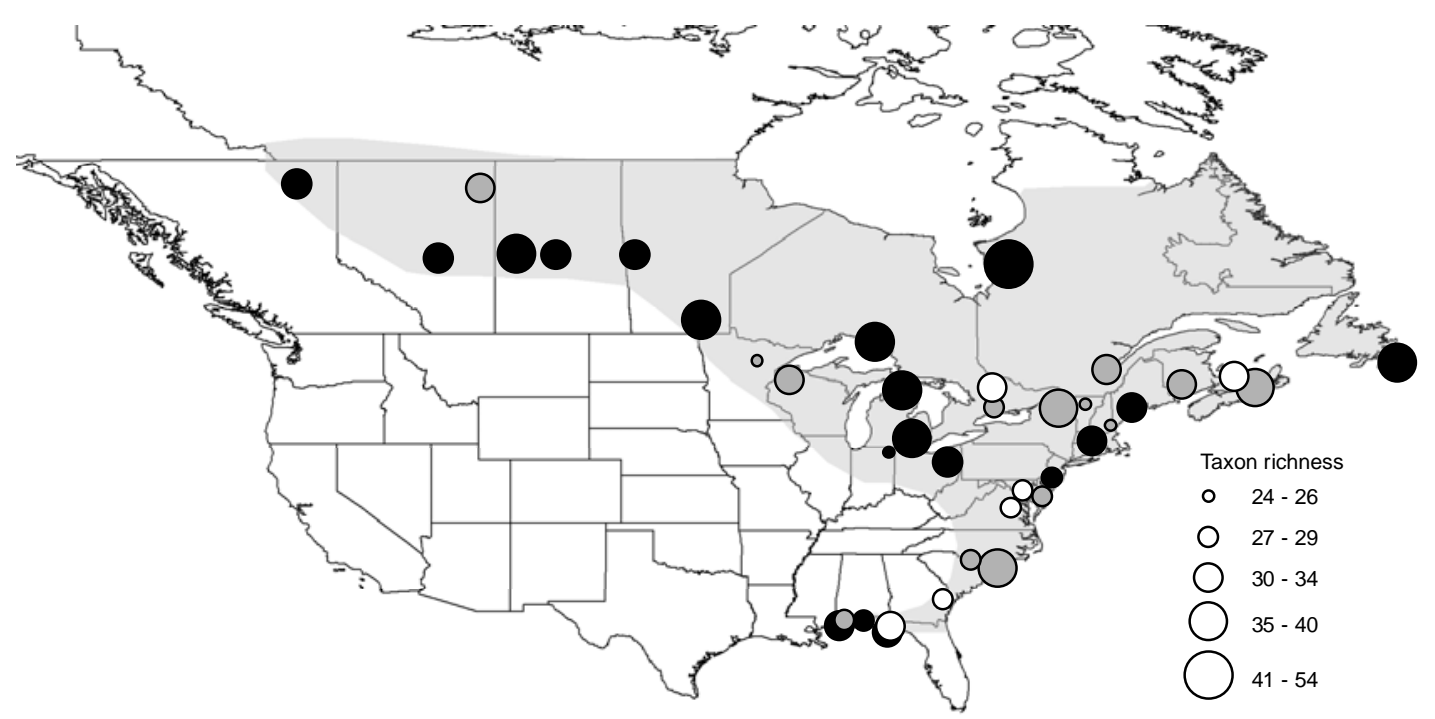


1 Figure 2
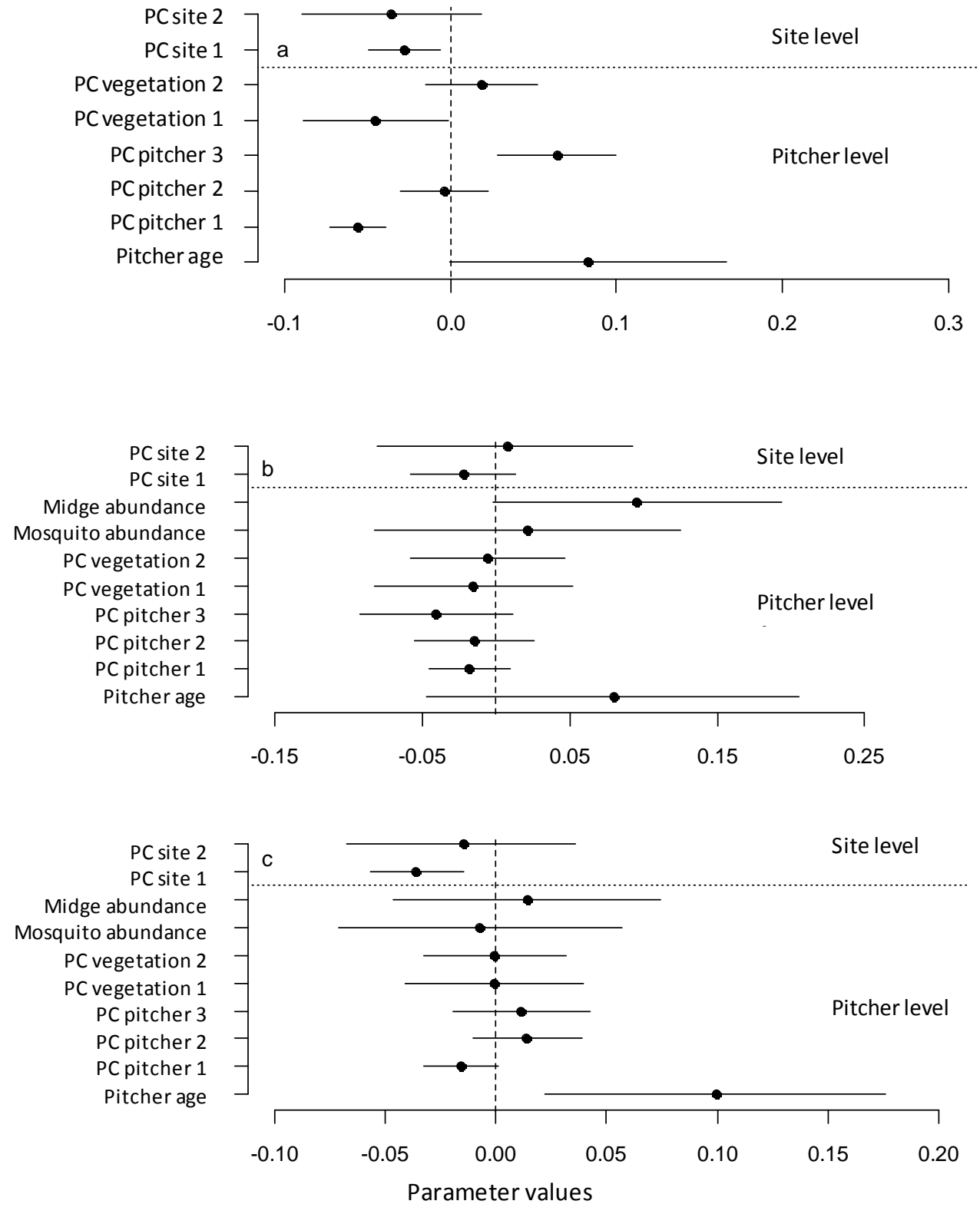
$1 \quad$ Figure 3
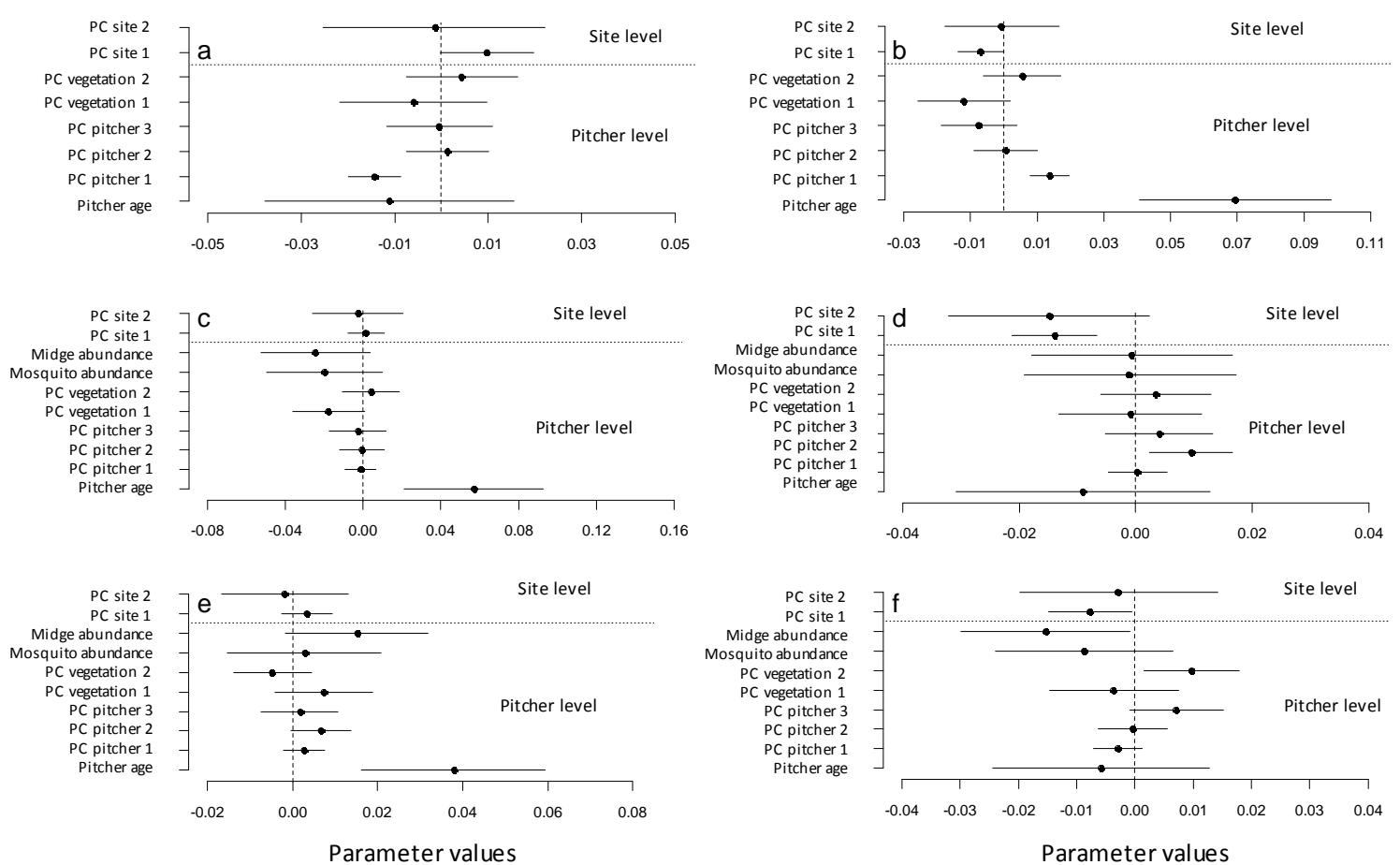
$1 \quad$ Figure 4
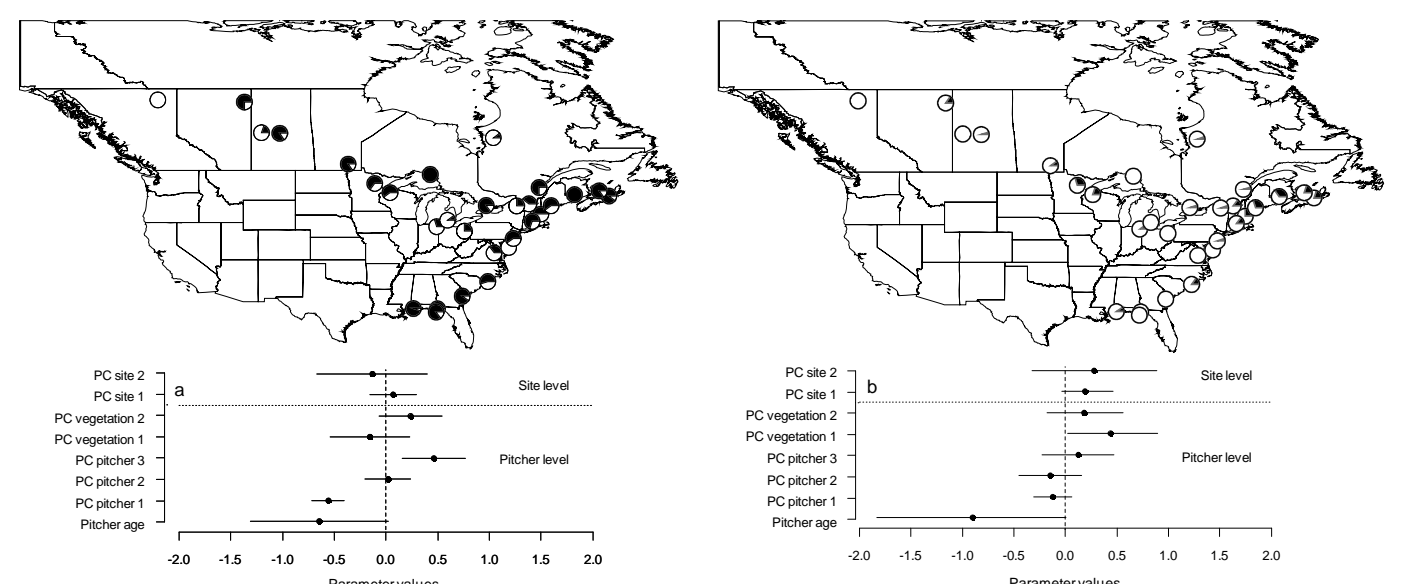

2
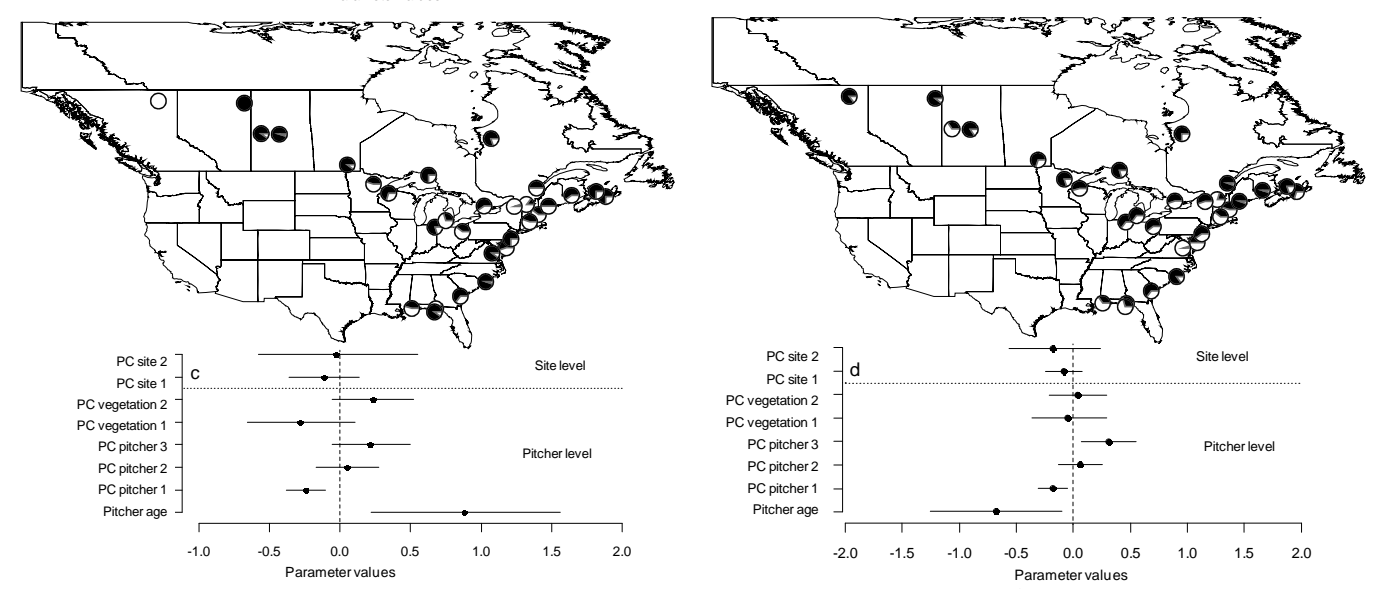

3
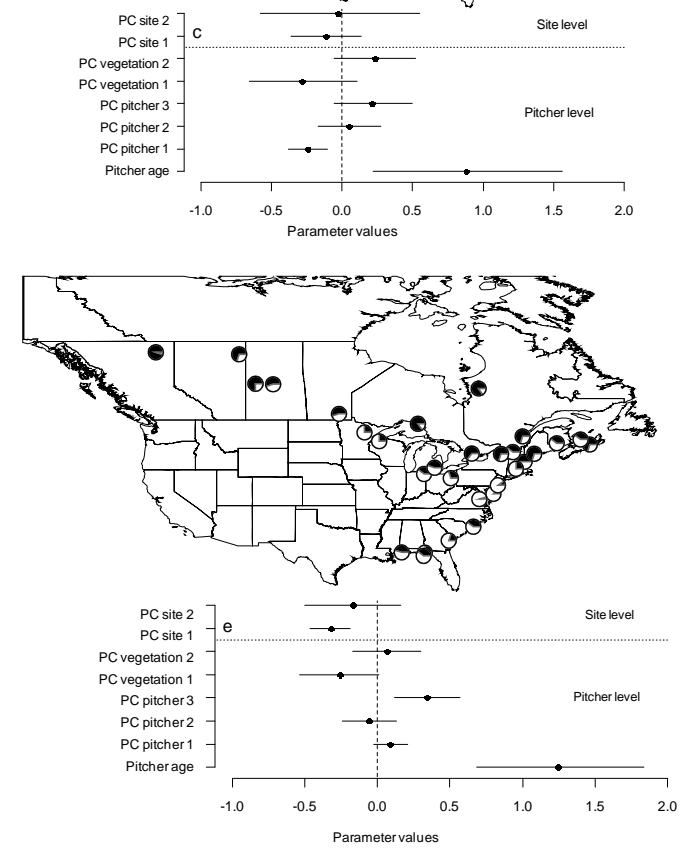
1 Appendix S1 Diagram of the food web occurring within the pitchers of the North American purple

2 pitcher plant, Sarracenia purpurea. Note that Fletcherimyia is uncommon in the southern part of the

3 host plant's range.

4

5

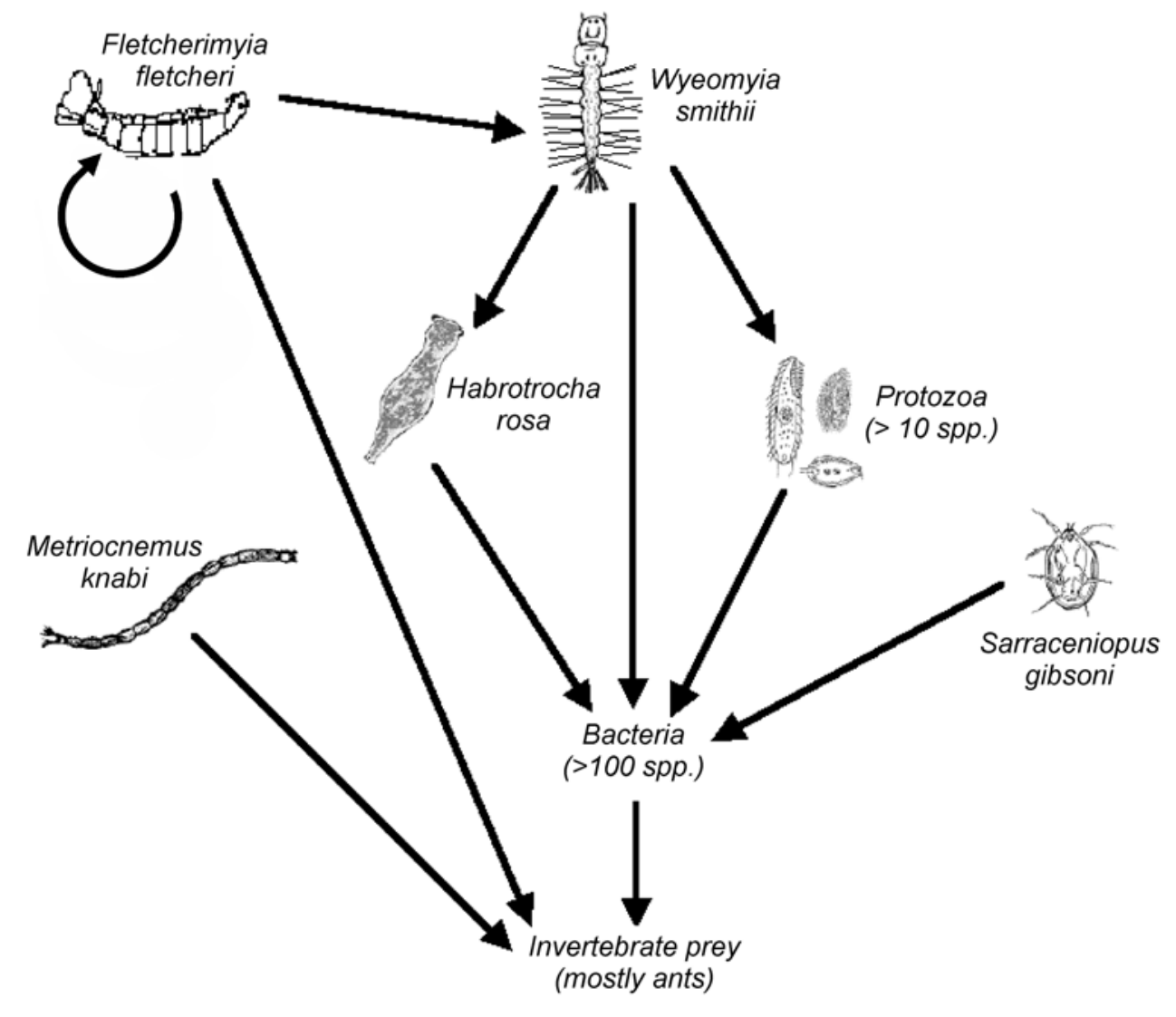


1 Appendix S2 The 56 taxa that occurred in $>1 \%$ of 780 pitcher-plant leaves sampled at thirty-nine sites

2 throughout the plant's North American range.

\begin{tabular}{|c|c|c|c|}
\hline Group & Species name & $\begin{array}{c}\text { Proportion of } \\
\text { pitchers }\end{array}$ & $\begin{array}{c}\text { Number of } \\
\text { sites }\end{array}$ \\
\hline \multirow[t]{13}{*}{ Arthropods and rotifers } & Metriocnemus knabi & 0.66 & 38 \\
\hline & Sarraceniopus gibsoni & 0.65 & 38 \\
\hline & Wyeomyia smithii & 0.64 & 37 \\
\hline & Habrotrocha rosa & 0.51 & 38 \\
\hline & rotifer sp. 'a' & 0.38 & 10 \\
\hline & unknown gastrotrich & 0.37 & 9 \\
\hline & unknown amphipod & 0.36 & 8 \\
\hline & unknown tardigrade & 0.36 & 8 \\
\hline & loricate rotifer & 0.33 & 13 \\
\hline & unknown cladoceran & 0.32 & 13 \\
\hline & Fletcherimyia fletcheri & 0.29 & 27 \\
\hline & unknown nematode & 0.27 & 13 \\
\hline & unknown copepod & 0.25 & 20 \\
\hline \multirow[t]{2}{*}{ Protozoan morphospecies } & Bodo sp. & 0.52 & 39 \\
\hline & Tachysoma sp. & 0.42 & 10 \\
\hline
\end{tabular}




\begin{tabular}{|c|c|c|c|}
\hline & Menoidium sp. & 0.41 & 8 \\
\hline & unknown sp. a & 0.38 & 5 \\
\hline & Peranema sp. & 0.33 & 17 \\
\hline & chrysomonads & 0.32 & 32 \\
\hline & Cryptomonas spp. & 0.31 & 14 \\
\hline & Petalomonas sp. & 0.31 & 9 \\
\hline & Anisonema sp. & 0.29 & 13 \\
\hline & Colpidium sp. & 0.29 & 34 \\
\hline & unknown sp. 'b' & 0.29 & 15 \\
\hline & Cyclidium sp. & 0.28 & 32 \\
\hline & Vorticella sp. & 0.28 & 5 \\
\hline & Euglena sp. & 0.26 & 8 \\
\hline & Paramecium sp. & 0.25 & 9 \\
\hline & Colpoda sp. 'big' & 0.24 & 37 \\
\hline & Notoselenus sp. & 0.23 & 6 \\
\hline & unknown sp. 'c' & 0.22 & 16 \\
\hline Bacterial morphotypes & Sphingomonas sp. 'a' & 0.89 & 39 \\
\hline & Sphingomonas sp. 'b' & 0.69 & 39 \\
\hline & Cytophagales & 0.57 & 39 \\
\hline
\end{tabular}




\begin{tabular}{|c|c|}
\hline Pseudomonas sp. & 0.50 \\
\hline Klebsiella pneumoniae & 0.49 \\
\hline morphotype number 46 & 0.46 \\
\hline Chromobacterium violaceum & 0.42 \\
\hline morphotype number 32 & 0.40 \\
\hline Flectobacillus sp. 'a' & 0.38 \\
\hline morphotype number 30 & 0.38 \\
\hline morphotype number 29 & 0.37 \\
\hline unknown yeast & 0.36 \\
\hline Microbacterium sp. & 0.36 \\
\hline Agrobacterium rhizogenes & 0.36 \\
\hline Chromobacterium sp. & 0.36 \\
\hline morphotype number 27 & 0.35 \\
\hline Rhodoferax sp. & 0.34 \\
\hline Sphingomonas sp. 'c' & 0.33 \\
\hline morphotype number 28 & 0.33 \\
\hline Chromobacterium sp. & 0.32 \\
\hline morphotype number 37 & 0.32 \\
\hline Flectobacillus sp. 'b' & 0.31 \\
\hline
\end{tabular}


morphotype number 24

Flectobacillus sp. 'c'

Bacillus sp. 
1 Appendix S3 Abundance-occupancy relationships for (a) arthropods + rotifers, (b) protozoans, and (c)

2 bacteria. Abundance was calculated as the mean number of individuals per pitcher where present.

3 Occupancy is the proportion of sites occupied out of thirty-nine. Abbreviations are as follows:

4 Mosquito $=$ Wyeomyia smithii, Chironomid $=$ Metriocnemus knabi, Mite $=$ Saraceniopus spp., Copepod

5 = unidentified copepod, Cladoceran = unidentified cladoceran, Fletcherimyia $=$ Fletcherimyia fletcheri,

$6 \quad$ Nematode $=$ unidentified nematodes, Amphipod $=$ unidentified amphipods, Gastrotrich $=$ unidentified

7 gastrotrichs, Tardigrade $=$ unidentified tardigrades, $H$. ros $a=$ Habrotroch $a$ rosa , Loricate rotifers $=$

8 Loricate rotifers, Unknown rotifer $=$ unidentified rotifer, ACISPP $=$ Acineta, AMOSPP $=$ unidentified

9 Amoeba, ANISPP = Anisonema, BODSP1 = Bodo sp1, CERSPP = Cercomonas, CHLSPP $=$

10 Chlamydodon, CHRSPP $=$ Chrysomonads, COLSP1 $=$ unidentified Colpidium sp., COPBIG $=$

11 unidentified Colpoda sp., COPSMA = Colpoda sp. small, CRYSPP = Cryptomonas, CYCSPP =

12 Cyclidium, EUGSPP = Euglena, EUPSPP = Euplotes, FLAGSP = unidentified flagellate, NOTSPP =

13 Notoselenus, PERSPP = Peranema, PETSPP = Petalomonas, SPISPP = Spirostomum, TACSPP =

14 Tachysoma, UNK19 = unidentified protozoan, UNKSP1 = unidentified protozoan, UNSP25 =

15 unidentified protozoan, VORSPP = Vorticella, SP1 = Sphingomonas, SP3 = Klebsiella $($ K. pneumoniae $)$,

16 SP10 = Flectobacillus, SP11 = Flectobacillus, SP14 = Flectobacillus, SP19= Bacillus $/$ soil bacterium,

17 SP20 = Chromobacterium, SP15, 24, 25, 27, 29, 31, 32, and $46=$ unknown bacterium. 

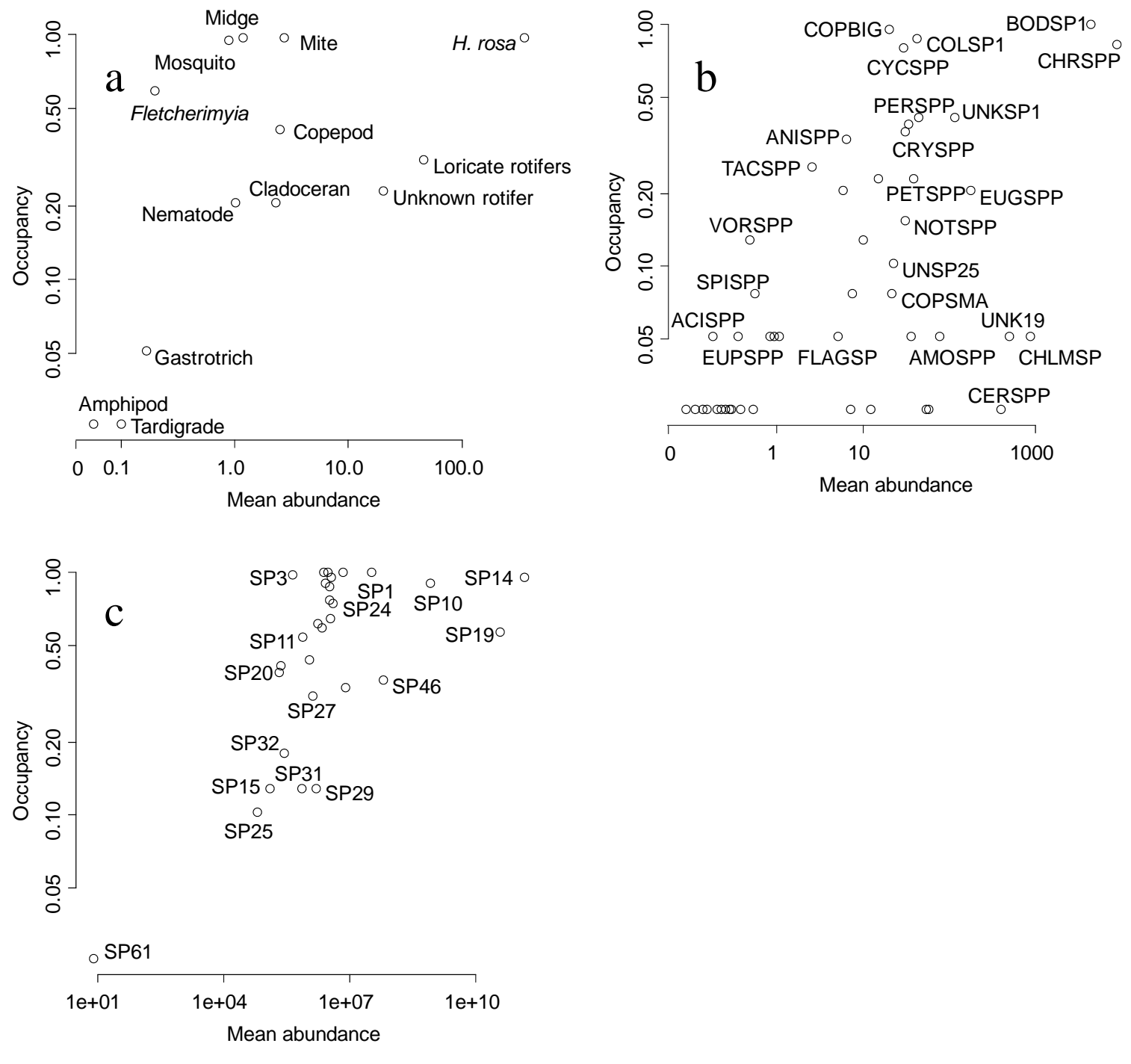
1 Appendix S4 Results from the principal-components analysis of pitcher- and plant-morphology

2 variables (pitcher level), vegetation variables measured within a $1-\mathrm{m}^{2}$ quadrat centred on each plant

3 (pitcher level), and site-level environmental variables. Values shown are the cumulative percentages of

4 variance accounted for by the axes shown and the loadings of each variable on each axis. Analyses

5 included data from seven southern sites at which soil pore-water data were not collected and two sites

6 with missing environmental data.

\begin{tabular}{|c|c|c|c|}
\hline Variable & Axis 1 & Axis 2 & Axis 3 \\
\hline \multicolumn{4}{|c|}{ Pitcher- and plant-morphology variables } \\
\hline Cumulative percent variation & 40.2 & 59.5 & 74.7 \\
\hline Pitcher width at base & -0.44 & -0.14 & 0.19 \\
\hline Aperture diameter & -0.42 & -0.19 & 0.29 \\
\hline Pitcher length from base to neck & -0.40 & -0.15 & -0.39 \\
\hline Fluid volume & -0.37 & -0.11 & 0.06 \\
\hline Rosette diameter & -0.36 & 0.14 & -0.40 \\
\hline Lip thickness & -0.31 & -0.04 & 0.52 \\
\hline Width of keel & -0.23 & -0.02 & -0.51 \\
\hline Number of water-filled leaves & -0.17 & 0.64 & 0.17 \\
\hline \multicolumn{4}{|l|}{ Vegetation variables } \\
\hline Cumulative percent variation & 37.1 & 63.8 & \\
\hline
\end{tabular}




\begin{tabular}{|c|c|c|}
\hline Sphagnum & 0.89 & -0.10 \\
\hline Shrubs & 0.48 & 0.50 \\
\hline Trees & -0.23 & 0.84 \\
\hline Graminoids & -0.34 & -0.57 \\
\hline Forbs & -0.81 & 0.19 \\
\hline \multicolumn{3}{|l|}{ Site-level environmental variables } \\
\hline Cumulative percent variation & 60.2 & 73.6 \\
\hline Mean monthly precipitation & 0.93 & -0.07 \\
\hline Mean monthly temperature & 0.90 & 0.14 \\
\hline Number of growing-season days & 0.89 & 0.13 \\
\hline Longitude & 0.80 & -0.12 \\
\hline Pore water $\mathrm{PO}_{4}$ & 0.16 & 0.79 \\
\hline Pore water $\mathrm{NH}_{4}$ & -0.43 & -0.50 \\
\hline Pore water $\mathrm{pH}$ & -0.56 & 0.73 \\
\hline Pore water $\mathrm{Ca}^{+2}$ & -0.71 & -0.04 \\
\hline Elevation & -0.72 & 0.29 \\
\hline Coefficient of variation in mean & -0.90 & 0.09 \\
\hline \multicolumn{3}{|l|}{ monthly precipitation } \\
\hline Latitude & -0.94 & -0.12 \\
\hline
\end{tabular}


monthly temperature 